\section{Insulin Receptor Degradation Is Accelerated in Cultured Lymphocytes from Patients with Genetic Syndromes of Extreme Insulin Resistance}

\author{
Aidan McElduff, José A. Hedo, Simeon I. Taylor, \\ Jesse Roth, and Phillip Gorden \\ Diabetes Branch, National Institute of Arthritis, Diabetes, \\ Digestive, and Kidney Diseases, National Institutes of Health, \\ Bethesda, Maryland 20205
}

A ceptor in disease states have utilized primarily techniques of equilibrium binding and, to a limited extent structural, analysis. Though techniques have been developed to study receptor degradation in normal cells, they have not been applied to disease states. In the present study we have examined insulin receptor degradation rate in B lymphocytes that were obtained from peripheral blood of normal subjects and patients with several syndromes of extreme insulin resistance. B lymphocytes were established in culture from each patient's peripheral cells by transformation with Epstein-Barr virus. The insulin receptors were surface labeled using $\mathrm{Na}^{125} \mathrm{I} /$ lactoperoxidase and the cells were returned to incubate in growth media. After varying periods of incubation, aliquots of cells were solubilized and the cell content of labeled receptor subunits were measured by immunoprecipitation with anti-receptor antibodies and $\mathrm{NaDodSO}_{4} /$ polyacrylamide gel electrophoresis. The fall in ${ }^{125} \mathrm{I}$-insulin receptor content approximated a single exponential and was quantitated as receptor subunit half-life $\left(t_{1 / 2}\right)$. In cell lines from four patients in whom the number of insulin receptors was reduced by $>90 \%$, the rate of receptor loss was greater than normal $\left(t_{1 / 2}\right.$ equals 3.8 \pm 0.9 h vs. $6.5 \pm 1.2 \mathrm{~h}$; mean $\pm \mathrm{SD}, P<0.01)$. However, a

Dr. A. McElduff is the holder of a National Health and Medical Research Council (Australia) C. J. Martin Fellowship and was the 1982 Bushell Traveling Fellow of the Royal Australasian College of Physicians. Address all correspondence to Dr. McElduff.

Received for publication 30 August 1983 and in revised form 18 April 1984.

J. Clin. Invest.

(C) The American Society for Clinical Investigation, Inc.

0021-9738/84/10/1366/09 \$1.00

Volume 74, October 1984, 1366-1374 similar acceleration in receptor degradation was seen in cells from five patients with extreme insulin resistance but low-normal insulin receptor concentration $\left(t_{1 / 2}\right.$ equals $4.4 \pm 0.9 \mathrm{~h}$ ). This group included cells from one patient with a qualitatively abnormal receptor. Thus, all the patients with genetic syndromes of insulin resistance had accelerated receptor degradation, regardless of their receptor concentration. By contrast, insulin receptors on cultured lymphocytes that were obtained from patients with extreme insulin resistance secondary to autoantibodies to the insulin receptor had normal receptor degradation ( $t_{1 / 2}$ equals $\left.6.1 \pm 1.9 \mathrm{~h}\right)$.

We conclude that $(a)$ accelerated insulin receptor degradation is an additional feature of cells from patients with genetic forms of insulin resistance; $(b)$ that accelerated insulin receptor degradation may explain the lownormal receptor concentrations that were seen in some patients with extreme insulin resistance; and (c) that accelerated degradation does not explain the decreased receptor concentration in patients with very low insulin receptor binding and, therefore, by inference, a defect in receptor synthesis must be present in this subgroup.

\section{Introduction}

Insulin resistance is an important etiologic factor in many disorders of carbohydrate metabolism (1). The insulin receptor is an important locus for examining the nature of insulinresistant states in both animals and humans (1-3). Insulin resistance may result from abnormalities of receptor regulation (3), autoantibodies against the receptor (4), primary defects in the insulin binding component (5-8), and from a variety of defects in post-binding events (9). In primary defects of the receptor, cultured cells, either fibroblasts $(7,8,10)$ or lymphocytes $(5,6)$, retain the in vivo receptor binding characteristics. This allows for direct studies of the receptor in vitro $(5-8,10)$. 
On the other hand, cultured cells from patients with extreme insulin resistance which resulted from autoantibodies directed against the insulin receptor (type B syndrome of extreme insulin resistance) (4) have normal binding in vitro and presumably normal insulin receptors (11).

The important determinants of receptor concentration in any cell type are the rates of receptor synthesis and degradation. The degradation rate of the insulin receptor has been measured in cultured cells from human and animals sources (12-18). However, degradation rates have not previously been measured in cells from patients with insulin resistance. In this study we have measured the degradation rates of insulin receptors in cultured lymphocytes from normal subjects: in three subgroups of patients with presumed genetic ${ }^{1}$ or primary insulin resistance, in one group with low-normal insulin receptor concentration, in one group with absolutely low insulin receptor concentration, and in one patient with a normal concentration of a qualitatively abnormal receptor. Finally, we have studied cultured cells from patients with a secondary cause for their insulin resistance, i.e., type B extreme insulin resistance (autoantibodies to the insulin receptor) (4).

\section{Methods}

\section{Materials}

$\mathrm{Na}^{125} \mathrm{I}$ and Triton X-100 were from New England Nuclear, Boston, MA; aprotinin, phenylmethylsulfonyl fluoride, and glucose oxidase (type V) were from Sigma Chemical Co., St. Louis, MO; lactoperoxidase was from Boehringer-Mannheim Biochemicals, Indianapolis, IN; staphylococcal protein A (pansorbin) was from Calbiochem-Behring Corp., San Diego, CA; and reagents from gel electrophoresis were from Bio-Rad Laboratories, Richmond, CA.

\section{Methods}

Patients. Blood was obtained from six normal subjects including one infant, from nine patients with various genetic syndromes of extreme insulin resistance, and from three subjects with autoantibodies to the insulin receptor (type B syndrome) (Table I). The patients were classified as normal or low insulin binders based on binding to their cultured lymphocytes. This classification was usually consistent with the binding to other cell types, but discrepancies do occur and have been discussed previously (5). Nevertheless, since this study was performed on the cultured lymphocytes, we have accepted classification of binding according to that cell type. In cells from the patients with the various genetic syndromes, this has resulted in one group of four patients with unequivocally low binding (percentage bound, $1.6 \pm 0.5$ vs. $42 \pm 19, P<0.002$, mean \pm SD) compared with the normal subjects, and one group of five patients with binding in the low-normal range (percentage bound, 21 \pm 8 ). We have called this group normal binders, since their binding is within the normal range, although the mean binding is statistically different from the mean of both the normal subjects $(P=0.05)$ and the low binders $(P<0.005)$. We have

1. Abbreviations used in this paper: We have used the term genetic here and previously, to mean that the defects are intrinsic to the cells and therefore present in cultured cells when circulating factors are removed. previously shown that the extremely low binding patients have a decrease in receptor concentration $(5,6,19,20)$. All studies were approved by the Human Studies Committee of the National Institute of Arthritis, Diabetes, Digestive and Kidney Diseases, National Institutes of Health, Bethesda, MD.

Establishment and growth of lymphoblastoid cell lines. Human lymphoblastoid cell lines that were prepared by infection of peripheral blood lymphocytes with Epstein-Barr virus $(21,22)$ were grown in RPMI 1640 medium that was enriched with $10 \%$ heat-inactivated fetal calf serum (Flow Laboratories, Inc., McLean, VA). These cells grow in suspension and have an insulin receptor concentration of $\sim 10$ 50,000 receptors/cell. For these two reasons they have been used for structural studies of the receptor. The cells have a doubling time of $\sim 24 \mathrm{~h}$. At the time of these studies, all cell lines had undergone multiple $(>50)$ doublings. Cells were grown until they achieved stationary growth phase (usually $1-2 \times 10^{6}$ cells $/ \mathrm{ml}$ ). The cells were then harvested by centrifugation and washed three times in phosphate-buffered saline.

Surface labeling of $\mathrm{Na}^{125} \mathrm{I}$. The cells were iodinated according to a modification of the method described by Kasuga et al. (12). In brief, the cells were suspended $\left(2-4 \times 10^{7} \mathrm{cells} / \mathrm{ml}\right)$ in phosphate-buffered saline that was supplemented with glucose $(20 \mathrm{mM})$, lactoperoxidase $(25 \mu \mathrm{g} / \mathrm{ml})$, glucose oxidase $(1,100 \mathrm{mU} / \mathrm{ml})$, and $\mathrm{Na}^{125} \mathrm{I}(50-100 \mu \mathrm{Ci} /$ $\mathrm{ml})$ at $25^{\circ} \mathrm{C}$ for $30 \mathrm{~min}$. After iodination, cells were washed three times in phosphate-buffered saline and returned to culture medium $\left(2-4 \times 10^{6}\right.$ cells $\left./ \mathrm{ml}\right)$. After this labeling procedure, the viability of the cells, as assessed by trypan blue exclusion, was $>90 \%$. The cells remained viable and metabolically active for the duration of these studies.

Receptor solubilization. After various times in culture, the labeled cells were washed three times in phosphate-buffered saline and once in $0.1 \mathrm{M}$ sodium phosphate buffer, $\mathrm{pH} 6.0$, which contained $1 \%$ bovine serum albumin. The cells were then solubilized in $1 \%$ Triton $\mathrm{X}-100$ (in $150 \mathrm{mM}$ sodium chloride, $50 \mathrm{mM}$ Hepes buffer, pH 7.6, containing phenylmethylsulfonyl fluoride $(1 \mathrm{mM})$ and aprotinin [0.85 trypsin inhibitor units per milliliter]) for $30 \mathrm{~min}$ on ice. After removal of insoluble materials by centrifugation $\left(200,000 \mathrm{~g}\right.$ for $45 \mathrm{~min}$ at $\left.4^{\circ} \mathrm{C}\right)$, the supernatants were used for immunoprecipitation.

Immunoprecipitation and electrophoresis of the insulin receptor. To immunoprecipitate the ${ }^{125} \mathrm{I}$-labeled receptors, anti-receptor antibody (either B-10 IgG, $70 \mu \mathrm{g} / \mathrm{ml}$, or B-2 antiserum, 1:400) $(4,23)$ was added to the detergent extract. These concentrations were demonstrated to immunoprecipitate $>95 \%$ of the insulin receptors. Control nonimmune precipitates were obtained by addition of either normal IgG (70 $\mu \mathrm{g} /$ $\mathrm{ml}$ ) or normal human serum (1:400) to separate aliquots of detergent extracts. The immune complexes were precipitated with pansorbin and prepared for $\mathrm{NaDodSO}_{4} /$ polyacrylamide gel electrophoresis as described previously (24) (Fig. 1). The radioactivity in labeled bands was quantitated by excising the bands from gels and measuring radioactivity in an autogamma counter (Nuclear Chicago Co., Des Plaines, IL).

Anti-receptor antibody. IgG fractions were prepared from the serum of a patient (B-10) (23) with type B extreme insulin resistance and from normal serum by protein A affinity chromatography (25). The final protein concentration of the IgG fraction that contained the antireceptor antibody was $3.5 \mathrm{mg} / \mathrm{ml}$. Serum from patient (B-2) (4) with type B extreme insulin resistance was used directly in some studies. In previous studies $(5,6,19)$, we have shown that the ability of antireceptor antibodies to inhibit ${ }^{125} \mathrm{I}$-insulin binding to cultured lymphocytes from normal subjects and subjects with extreme insulin resistance (including three of the low binders studied here) was identical. This was in contrast to studies in fibroblasts where significant differences in 
Table I. Clinical and Laboratory Data on the Normal Subjects and Patients with Insulin Resistance

\begin{tabular}{|c|c|c|c|c|c|c|c|c|c|c|c|c|}
\hline \multirow[b]{3}{*}{ Patient \# } & \multirow[b]{3}{*}{ Diagnosis } & \multirow[b]{3}{*}{ Age/sex } & \multirow[b]{3}{*}{$\begin{array}{l}\text { Fasting } \\
\text { insulin }\end{array}$} & \multirow[b]{3}{*}{$\begin{array}{l}\text { Fasting plasma } \\
\text { glucose }\end{array}$} & \multicolumn{8}{|c|}{${ }^{125} \mathrm{I}$-Insulin bound } \\
\hline & & & & & \multicolumn{2}{|c|}{$\begin{array}{l}\text { Cultured B } \\
\text { lymphocytes }\end{array}$} & \multicolumn{2}{|c|}{$\begin{array}{l}\text { Circulating } \\
\text { erythrocytes }\end{array}$} & \multicolumn{2}{|c|}{$\begin{array}{l}\text { Circulating } \\
\text { monocytes }\end{array}$} & \multicolumn{2}{|c|}{$\begin{array}{l}\text { Cultured } \\
\text { fibroblasts }\end{array}$} \\
\hline & & & & & bound* & $E D_{50}$ & bound & $\mathrm{ED}_{\text {so }}$ & bound" & $\mathrm{ED}_{\mathbf{s 0}}$ & bound§ & $\mathrm{ED}_{\mathbf{s 0}}$ \\
\hline & & $y r$ & mU/liter & $m g / d l$ & $\%$ & $n g / m l$ & $\%$ & $n g / m l$ & $\%$ & $n g / m l$ & $\%$ & $n g / m l$ \\
\hline 1 & Norm Vol & $40 / \mathrm{M}$ & - & - & 35 & 5.0 & - & - & - & - & - & - \\
\hline 2 & Norm Vol & $0.5 / \mathrm{M}$ & - & - & 60 & 6.0 & - & - & - & - & - & - \\
\hline 3 & Norm Vol & $22 / F$ & - & 87 & 49 & 3.5 & - & - & - & - & - & - \\
\hline 4 & Norm Vol & $20 / \mathrm{M}$ & 6 & 82 & 62 & 4.7 & 9.6 & 5.3 & 4.6 & 3.0 & - & - \\
\hline 5 & Norm Vol & $22 / \mathrm{M}$ & - & 81 & 12.5 & 2.5 & - & - & - & - & - & - \\
\hline 6 & Norm Vol & $17 / \mathrm{M}$ & - & - & 32 & 2.1 & - & - & - & - & - & - \\
\hline $7(28)$ & Lepre & $3 / F$ & $>100$ & $<40$ & 18 & 1.7 & - & - & - & - & - & - \\
\hline 8 & Typ A (A4) & $24 / F$ & 70 & 85 & 15 & 7.0 & 3.8 & 5.5 & 3.0 & 1.8 & 3 & 2 \\
\hline $9(4,8)$ & Typ A (A3) & $21 / F$ & 300 & 70 & 12 & 3.1 & 2.3 & 15.0 & 1.6 & 6.0 & 1.2 & $5^{\prime \prime}$ \\
\hline $10(31)$ & Lipo Diab & $17 / F$ & - & - & 30 & 3.6 & - & - & - & - & - & - \\
\hline $11(31)$ & Lipo Diab & $19 / \mathrm{F}$ & 125 & $>250$ & 29 & 2.3 & 9.3 & 6.0 & 3.2 & 3.5 & - & - \\
\hline 12 & Typ A (A5) & $18 / \mathrm{F}$ & - & - & 2 & 1.9 & 0.8 & - & 0.7 & - & 1.65 & 40 \\
\hline $13(6,8)$ & Lepre & $0.1 / F$ & 500 & 40 & 1.9 & 4.5 & - & - & - & - & 1.0 & 35 \\
\hline $14(4,6-8)$ & Typ A (A1) & $20 / F$ & 125 & 200 & 1.4 & 2.0 & 0.9 & - & 0.5 & 1.4 & 1.6 & 35 \\
\hline \multirow[t]{2}{*}{$15(5,32)$} & Rabson-Men & $16 / \mathrm{M}$ & - & $>200$ & 1.0 & - & 0.5 & - & - & - & 1.6 & 90 \\
\hline & & & & Normal ranges: & $12-62$ & $1.5-8$ & $2.5-11$ & $2-20$ & $3-11$ & $0.6-5.0$ & $3-7$ & $2-5$ \\
\hline
\end{tabular}

* Per $10^{7}$ cells $/ \mathrm{ml}$. $\ddagger$ Per $4.5 \times 10^{9}$ cells $/ \mathrm{ml}$. $\S$ Per $5 \times 10^{6}$ cells $/ \mathrm{ml}$. "This patient is the only patient that we have studied who has low binding in vivo, low binding to fibroblasts, but normal binding to cultured lymphocytes. Norm Vol, normal volunteer, Lepre, leprechaunism; Typ A, Type A diabetes; Lipo Diab, lipoatrophic diabetes; and Rabson-Men, Rabson-Mendenhall Syndrome. Parentheses indicate reference numbers.

the pattern of antibody inhibition of ${ }^{125}$ I-insulin binding to cells from the same subjects were observed (8). The explanation for these differences is not clear, but may be related to the presence of growth factor receptors on the fibroblasts (20). However, it seems unlikely that the results in this study are due to differences in antibody recognition among the subgroups studied.

Calculations. The regions of the polyacrylamide gels in which the insulin receptor subunits migrate contain two radioactive components: the ${ }^{125}$ I-labeled insulin receptor ("specific"), as well as ${ }^{125}$ I not directly associated with the insulin receptor ("nonspecific"). We have estimated the "nonspecific" component of radioactivity by performing parallel nonimmune precipitation and excising the relevant region of the gel corresponding to the specific immunoprecipitates. In previous studies with IM-9 cells, this "nonspecific" component had been considered to be negligible (12). However, in the present studies we found it necessary to correct for the "nonspecific" radioactivity for two reasons:

1. The cells that were studied here have fewer insulin receptors than IM-9 cells. Thus, the "specific" radioactivity was a smaller fraction of the total. 2. The use of an anti-receptor IgG (B-10) with a lower anti-receptor activity necessitated the addition of more antibody to achieve immunoprecipitation. The increase in the concentration of IgG appeared to increase the amount of radioactivity nonspecifically trapped. In general, the "nonspecific" radioactivity was smaller in the 135,000 -mol wt region than in the 95,000 -mol wt region. For these reasons, the data for the 135,000 -mol wt subunit with the nonspecific correction are presented in detail (Figs. 2-4), and the uncorrected data for both the 135,000 - and 95,000 -mol wt subunits are summarized in Table II.

Densitometry. Densitometry was performed on a GS 300 transmittance/reflectance scanning densitometer from Hoefer Scientific Instruments, San Francisco, CA, and recorded by an LKB 2210-2 channel recorder (LKB, Stockholm, Sweden).

Statistical methods. The regression lines were fitted using least squares linear regression, and the derived fit was used to calculate the receptor half-life. Comparisons between the mean half-lives of the various subgroups was made using a two-tailed $t$ test.

\section{Results}

Cell surface iodination and measurement of insulin receptor degradation. The cell surfaces of cultured lymphocytes from normal subjects and patients with insulin resistance were iodinated under conditions where the cells remained viable and metabolically active when returned to the culture. At intervals, cells were removed for study; ${ }^{125} \mathrm{I}$-insulin receptors from these cells were solubilized, immunoprecipitated with anti-receptor antibody, and analyzed by gel electrophoresis. As we have shown previously (5), the major subunits of the receptor (Fig. 1, lane A) were identified at 135,000 and 95,000 mol wt. These were of similar molecular weight to those seen 
TURNOVER OF ${ }^{125}$ I-LABELED RECEPTOR (Normal Subject)

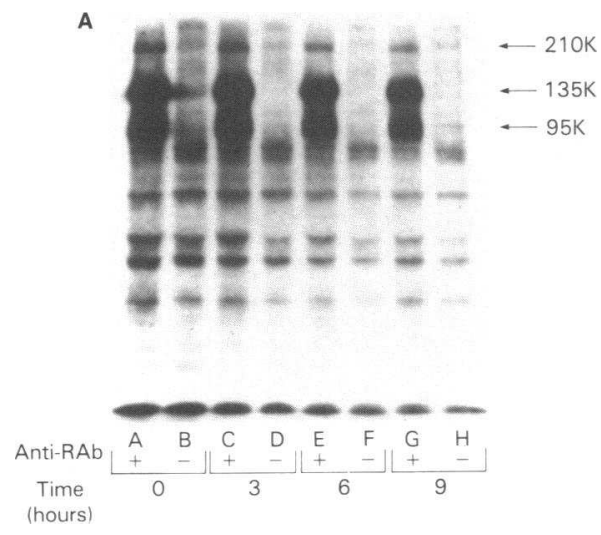
TURNOVER OF 125 I-LABELED RECEPTOR
(TYPE A/A1)

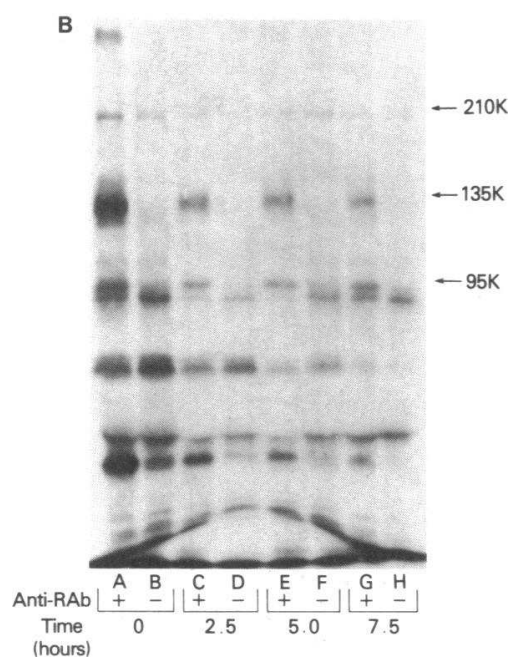

Figure 1. Time course of ${ }^{125} \mathrm{I}$-receptor degradation $(A)$ in cells from a normal subject and $(B)$ in cells from a patient with extreme insulin resistance and low receptor concentration (patient 14 in Table I). The surface proteins of cultured B lymphocytes were iodinated with ${ }^{125} \mathrm{I} /$ lactoperoxidase and returned to culture for the times shown. At that point the cells were solubilized and the ${ }^{125}$ I-receptors for insulin immunoprecipitated with either anti-receptor antiserum (Anti-Rab+) or control serum (Anti-Rab-) and run on $\mathrm{NaDodSO}_{4} /$ polyacrylamide gels. An autoradiograph of the gel is shown. Specifically immunoprecipitated insulin receptor subunits were identified at $210,000(210 \mathrm{~K})$, $135,000(135 \mathrm{~K})$, and 95,000 (95K) mol wt. in other cell types using iodination (12) or other radiolabeling methods $(26,27)$. A minor subunit component of 210,000 mol wt was also seen (24). Its degradation rate was not calculated due to the small quantity of this subunit present in these cells. The fall with time in ${ }^{125}$ I subunits was a single exponential that was consistent with a first order degradation process (Fig. 2, $A$ and $B$ ). The rate of degradation was therefore quantified as the half-life of the individual receptor subunits $\left(t_{1 / 2}\right)^{2}$

The results of three separate studies performed on the cells from a normal infant and from a patient with leprechaunism are shown in Fig. 2, $A$ and $B$. The reproducibility of the measurements are clearly shown. When insulin receptor degradation was examined in cells from six normal control subjects, the mean half-life of the 135,000 -mol wt subunit was $6.5 \pm 1.2 \mathrm{~h}$ (mean $\pm \mathrm{SD})$.

Degradation of the 135,000-mol wt in patients with decreased ${ }^{125}$ I-insulin binding. In four of our patients, insulin resistance resulted from a decrease in the number of insulin receptors $(5,6,20)$. When cells from these patients were labeled with ${ }^{125} \mathrm{I} /$ lactoperoxidase, there was a marked reduction of ${ }^{125} \mathrm{I}$ labeled receptor detectable in detergent extracts of the cells. The extent of this reduction was proportional to the reduction in tracer ${ }^{125}$ I-insulin binding to the cells (data not shown). Despite this, the insulin receptor subunits could be identified (Fig. $1 B$ ) and the half-lives quantitated (Fig. 3, $A-D$ ). The degradation rate of the 135,000 -mol wt subunits in these low binding cells was accelerated $\sim 40 \%$, with a mean half-life of $\sim 3.8 \pm 0.9$ h $(P<0.01$ vs. normal control) (Fig. 4$)$.

To insure that overall protein turnover was not different among the cell lines studied, a nonspecific band of $\sim 55,000$ mol wt present in all subjects was evaluated with respect to its

2. $t_{1 / 2}$, receptor subunit half-life. turnover rate. No differences were found among the three groups studied (Table II).

Degradation of the 135,000-mol wt subunit in patients with insulin resistance and low-normal ${ }^{125}$ I-insulin binding. In five of our insulin-resistant patients, cultured lymphocytes had a low normal number of insulin receptors. When receptor degradation was studied in cells from these five patients, the mean
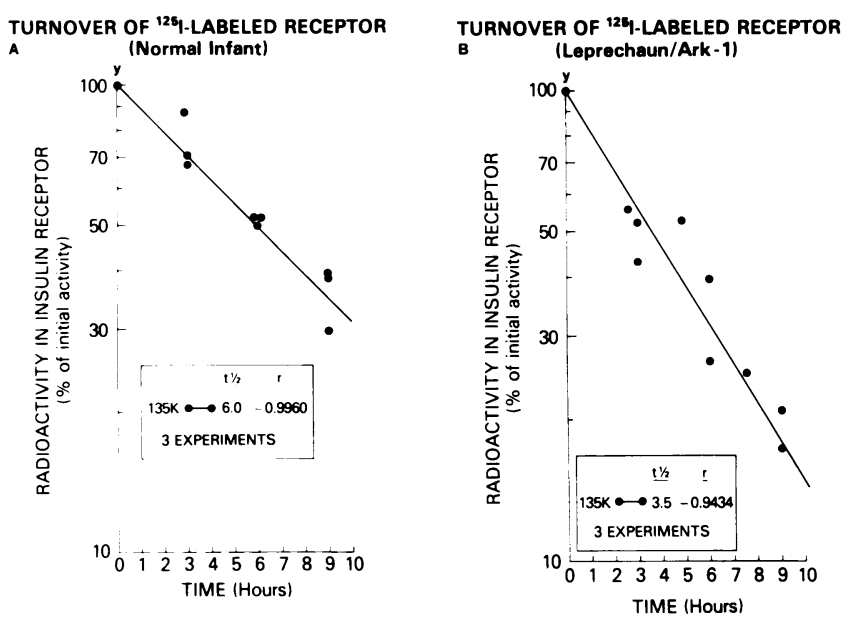

Figure 2. Time course of ${ }^{125} \mathrm{I}$-receptor degradation from $(A)$ a normal subject and $(B)$ a patient with extreme insulin resistance (patient 7 in Table I). Cells were processed as described in Fig. 1. The amount of radioactivity specifically immunoprecipitated in the 135,000 -mol wt band was quantitated and expressed as a percentage of the initial amount. The quantity of radioactivity (y axis) is plotted against the time in culture after surface labeling. Each cell type was studied on three separate occasions. Linear regression analysis was used to approximate the single exponential decay (correlation coefficient equals r). $135 \mathrm{~K}, 135,000 \mathrm{~mol} \mathrm{wt}$. 
TURNOVER OF 125I-LABELED RECEPTOR

A (Rabson-Mendenhall Syndrome)
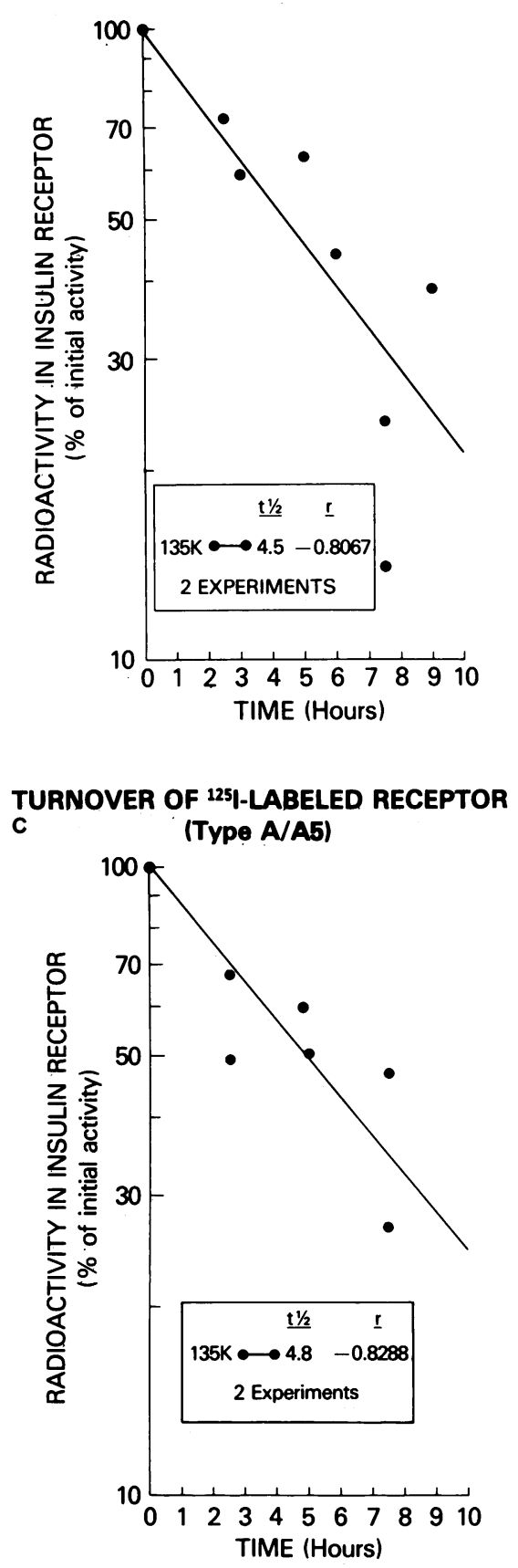

\section{TURNOVER OF ${ }^{125}$ |-LABELED RECEPTOR \\ B}

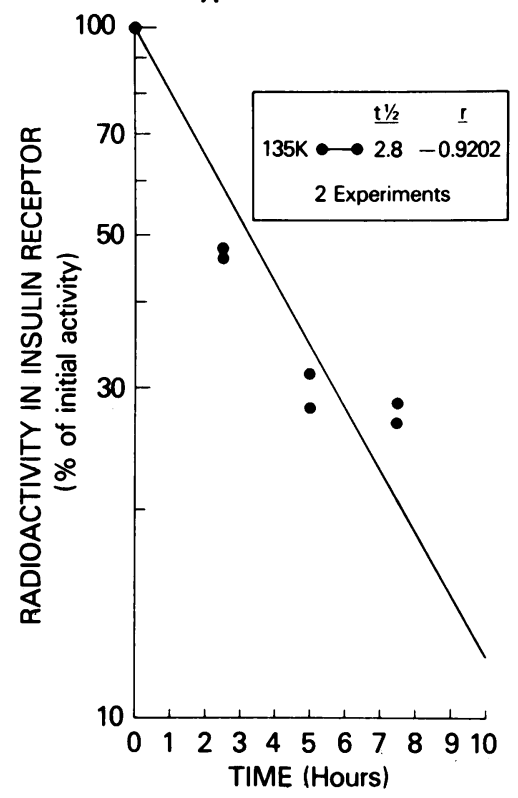

TURNOVER OF ${ }^{125}$ I-LABELED RECEPTOR

D (Leprechaun/Minn-1)

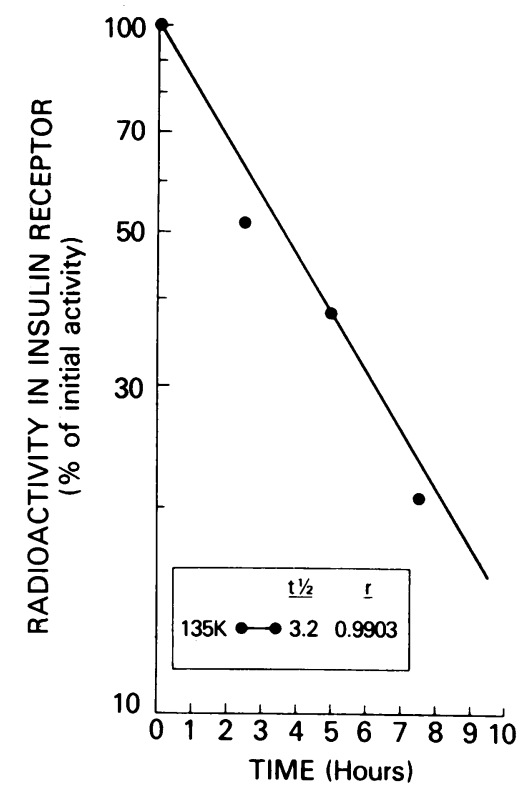

Figure 3. Time course of ${ }^{125}$ I-receptor degradation in cells from four patients with low receptor concentration. The cells from four patients with extreme insulin resistance and low receptor concentration were iodinated and processed as described in Figs. 1 and 2. Patients' diagnoses are $(A)$ the Rabson-Mendenhall Syndrome (patient 15 in Table I), (B) type $\mathrm{A}$ insulin resistance (patient 14 in Table $\mathrm{I}$ ), $(C)$ type $\mathrm{A}$ insulin resistance (patient 12 in Table I), and $(D)$ leprechaunism (patient 13 in Table I). 135K, 135,000 mol wt. degradation rate of the 135,000 -mol wt subunit was $4.4 \pm 0.9$ h $(P<0.01$ vs. normal controls) (Fig. 4). Thus, insulin receptor degradation was faster than in normal cells but indistinguishable from cells of patients with unequivocal low binding $(P>0.05)$ (Fig. 4). One of the patients with a normal number of receptors has been shown to have a qualitatively abnormal receptor (28). This receptor has a higher affinity than normal and the affinity is resistant to the changes that were induced by variations in $\mathrm{pH}$, temperature, and purification over lectin columns (28). The degradation rate of the $135,000-\mathrm{mol} \mathrm{wt}$ subunit of this abnormal receptor was $3.5 \pm 0.6 \mathrm{~h}(n=3)$ (Fig. $2 B$ ) (i.e., indistinguishable from other insulin-resistant patients with either normal or low insulin binding) (Fig. 4).

Degradation of the 135,000- and 95,000-mol wt subunits- 
Table II. Half-Lives of a Nonspecifically Precipitated Protein in Patients Grouped According to Receptor Status

\begin{tabular}{ll}
\hline Subgroup & Half-life \\
\hline $\begin{array}{l}\text { Normal subjects }(n=6) \\
\begin{array}{l}\text { Patients with insulin resistance and normal } \\
\text { receptor concentration }(n=5)\end{array}\end{array}$ & $6.2 \pm 1.3^{*}$ \\
$\begin{array}{l}\text { Patients with insulin resistance and low } \\
\text { receptor concentration }(n=4)\end{array}$ & $5.7 \pm 1.3 \quad(P>0.2$ vs. normal) \\
& $5.2 \pm 1.3 \quad(P>0.2$ vs. normal)
\end{tabular}

* Mean \pm SD (hours).

Cells from all the control subjects and patients were iodinated and processed as described in Fig. 1. The autoradiographs of each subject were scanned densitometrically to determine the radioactivity associated with the nonspecifically immunoprecipitated protein of $\sim 55,00 \mathrm{~mol}$ wt at each time point. Linear regression was then performed to determine the half-life of the protein. The correlation coefficients of the calculated line were $>0.9$ in all but one case.

corrected and uncorrected for the nonspecific component. As pointed out previously (see Methods), all the data up to this point have been corrected for the radioactivity on the gel immunoprecipitated by normal serum (i.e., nonspecific component). When the nonspecific correction was not carried out, the $t_{1 / 2}$ of the 135,000 -mol wt component for the normal and patients groups are similar (Table III). This is true because the nonspecific component at all time points is a much higher proportion of the radioactivity in subjects with low binding and low receptor concentration. This is even a greater problem for the 95,000-mol wt subunit (Table III). Thus, we do not feel that these uncorrected data are reliable but present them here for completeness. In previous studies using IM-9 lymphocytes, the turnover rates for the 135,000- and 95,000-mol wt components were similar, which suggested that degradation of the two receptor subunits occurs in parallel $(12,18)$. The estimates of receptor turnover (especially for the $95,000-\mathrm{mol}$ wt subunit) in those studies may have been more precise for technical reasons: IM-9 lymphocytes have more insulin receptors than do the cultured cells employed in these studies; and the use of a higher titer anti-receptor antiserum (B-2) in those studies led to a reduction in nonspecific immunoprecipitation.

Degradation of the 135,000-mol wt subunit in cultured lymphocytes from patients with autoantibodies to the insulin receptor (type B syndrome). Until now we have discussed data that was derived from patients with intrinsic cellular abnormalities that may be expected to be retained in tissue culture. In order to establish further specificity for accelerated receptor degradation in these syndromes of extreme insulin resistance, we have studied three cell lines that were derived from patients who manifested extreme insulin resistance in vivo secondary to autoantibodies to the insulin receptor. Under these conditions, the insulin receptor is presumed to be normal when not associated with the autoantibody (11). ${ }^{125}$ I-insulin binding in these cell lines is in the low-normal range (Table IV). Nevertheless, when the degradation of the 135,000-mol wt subunit was studied in these cells (Table IV), it was indistinguishable from normal (Fig. 4) and distinct from the accelerated degradation
Table III. Comparison of Receptor Half-Lives Calculated by Two Different Methods

\begin{tabular}{llc}
\hline & $\begin{array}{c}\text { Corrected } \\
\text { for nonspecific }\end{array}$ & $\begin{array}{c}\text { Not corrected } \\
\text { for nonspecific }\end{array}$ \\
\hline $\begin{array}{l}\text { A. } 135,000 \text {-mol wt subunit } \\
\text { Normal subjects }(n=6) \\
\text { Patients with insulin resistance } \\
\text { and normal receptor } \\
\text { concentration }(n=5)\end{array}$ & $6.5 \pm 1.2^{*}$ & $6.6 \pm 1.1$ \\
$\begin{array}{l}\text { Patients with insulin resistance } \\
\text { and low receptor } \\
\text { concentration }(n=4)\end{array}$ & $4.4 \pm 0.9$ & $5.1 \pm 1.6$ \\
$\begin{array}{l}\text { B. } 95,000 \text {-mol wt subunit } \\
\text { Normal subjects }(n=4) \\
\text { Patients with insulin resistance } \\
\text { and normal receptor } \\
\text { concentration }(n=3)\end{array}$ & $3.8 \pm 0.9$ & $6.6 \pm 1.7$ \\
$\begin{array}{c}\text { Patients with insulin resistance } \\
\text { and low receptor } \\
\text { concentration }(n=4)\end{array}$ & $6.4 \pm 1.4$ & $8.2 \pm 2.2$ \\
\hline
\end{tabular}

* Mean \pm SD (hours)

¥ In two normal subjects and two patients with normal receptor concentration, the half-lives of the 95,000 -mol wt subunit could not be estimated due to excessive nonspecific immunoprecipitation in this region.

that was seen in the subgroups of cells that were derived from patients with primary, genetic syndromes of extreme insulin resistance.

\section{Discussion}

Previously, the insulin receptor in disease states has been studied primarily by equilibrium-binding techniques (1-3) and to a limited extent by structural analysis $(5,6)$. In the present study we add a new technique to the study of receptor diseases. We have studied quantitatively the degradation rate of the insulin receptor in several genetic syndromes of extreme insulin resistance, and find that cells with either low-normal or absolutely low binding have accelerated rates of receptor degradation. The specificity of accelerated receptor degradation in these genetic syndromes is further shown by demonstrating normal degradation rates in cell lines derived from patients with autoantibodies to the insulin receptor. In this syndrome, the presence of the autoantibody confers extreme insulin resistance in vivo, but cells derived from these patients would be expected to be normal, in vitro, when the autoantibody is no longer present (11).

Although the iodination techniques we have employed leads to a covalent modification of the receptor, we have previously shown that it gives results identical to those achieved with biosynthetic labeling (12). Furthermore, normal and patient cells were studied using the same technique.

The turnover rates of the nonspecifically precipitated protein from the three subgroups are similar, and suggest the accelerated insulin receptor degradation is not part of a general phenom- 


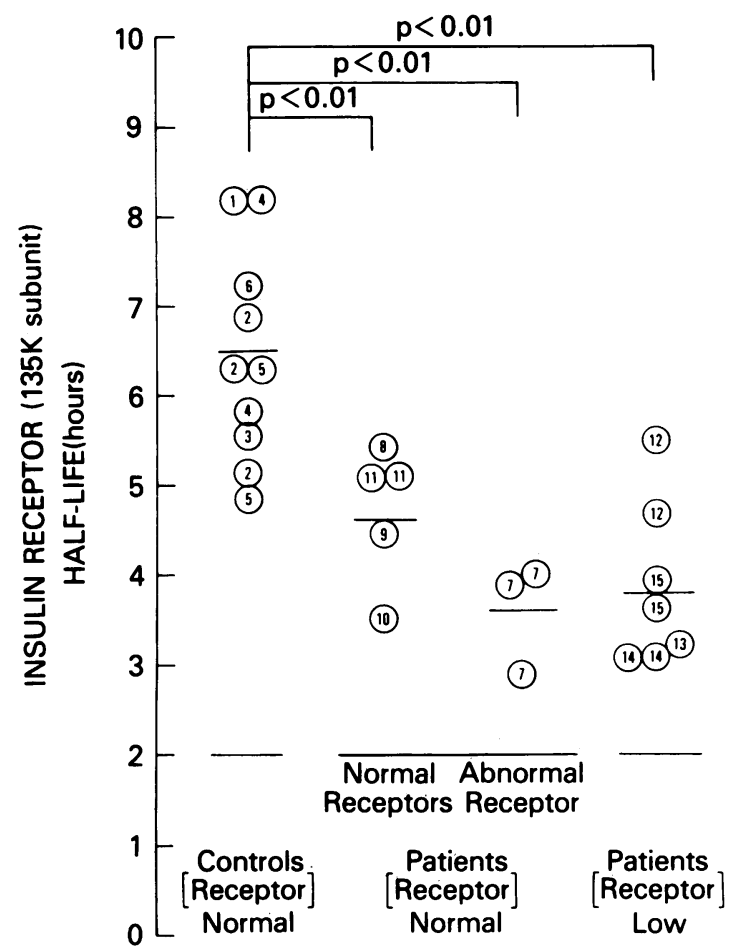

Figure 4. Receptor half-lives in patients grouped according to receptor status. Cells from all the control subjects and patients were iodinated and processed as described in Fig. 1. Individual half-lives for the 135,000-mol wt subunits were calculated as described in Fig. 2. Each symbol (o) represents an individual study, and the number identifies the patient as in Table I. The half-lives are grouped according to the patient's classification with regard to receptor status. The horizontal lines show weighted means of each group. 135K, 135,000 mol wt.

enon in cells derived from the patients. Rates of insulin receptor degradation have been estimated in other cell types using a variety of methods (Table V). It can be seen that the rates described in this paper are within the range of rates

Table IV. Insulin Binding Characteristics and Insulin Receptor Half-Lives in B Lymphocytes from Three Patients with Type B Extreme Insulin Resistance

\begin{tabular}{llll}
\hline Patient & $\begin{array}{l}\text { Insulin binding } \\
\text { cultured B } \\
\text { lymphocytes }\end{array}$ & $\mathrm{ED}_{\mathbf{5 0}}$ & $\begin{array}{l}\text { Receptor } \\
\text { half-life } \\
\left(t_{1 / 2}\right)\end{array}$ \\
\hline & $\% B / 10^{7}$ cells $/ \mathrm{ml}$ & $n g / m l$ & $h$ \\
B5 & 9 & 3.4 & 4.9 \\
B8 & 11 & 2.2 & 8.2 \\
B10 & 34 & 2.9 & $5.1^{*}$ \\
$\overline{\mathbf{x}} \pm$ SD & $18 \pm 14$ & $2.8 \pm 0.6$ & $6.1 \pm 1.9$
\end{tabular}

* This study was repeated on a separate occasion and an identical estimate of the half-life was obtained. described in other cell types (12-18). However, this is the first estimation of receptor turnover in cells from patients with insulin resistance; therefore, controls for these studies were cells cultured from normal subjects that were processed identically to the patients' cells.

The EBV-transformed lymphocytes $(5,6)$ used in this study preserve the insulin receptor phenotype (5) of these insulin-resistant patients. Moreover, these cells have certain features that facilitate the technical aspect of these studies: growth in suspension, a relatively large number of insulin receptors per cell, and the absence of receptors for insulinlike growth factor which might complicate interpretation of the results $(5,20)$.

Receptor degradation is accelerated in patients with genetic syndromes of insulin resistance. The significance of modestly accelerated turnover of insulin receptors in cells from the patients with the genetic syndromes that cause insulin resistance is unclear. It is tempting to speculate, however, that it reflects an abnormality in the receptors of these patients. In the one patient with insulin resistance, normal receptor concentration, and a qualitatively abnormal receptor (28), the half-lives of the 135,000 - and $95,000-\mathrm{mol} \mathrm{wt}$ subunits were $3.5 \pm 0.6$ and $3.4 \pm 0.7(n=3) \mathrm{h}$, respectively (Fig. $2 B$ ). It is possible that this qualitatively abnormal receptor is turned over rapidly because it is recognized by the cells as being abnormal, although the actual abnormality remains to be defined. Clearly, more sensitive methods will be necessary to detect these putative defects in other patients.

Mechanisms responsible for reduced cell surface receptor concentration. To maintain normal insulin receptor concentration in the face of increased degradation of the receptor, receptor synthesis must increase. In those cells with the low receptor concentration, this compensatory increase in receptor synthesis fails to occur. Further, in this subgroup, the reduction in receptor concentration is $>90 \%$ as compared with normal. A $40 \%$ increase in the degradation rate does not account for the degree of receptor loss in the low binding subgroup and suggests a major defect in receptor synthesis. On the other hand, it is possible that, with unaltered receptor synthesis, an accelerated receptor degradation of $\sim 40 \%$ could account for the decreased binding in the low-normal subgroup of patients where binding is decreased to $\sim 50 \%$ of normal. However, the turnover rates of the receptor in patients with type B extreme insulin resistance (Table IV) suggest this is too simple an interpretation.

Production, or "synthesis", of the mature insulin receptor and its insertion in the plasma membrane is a complex, multistep process. The receptor consists of at least two complex glycoprotein subunits, which are derived from a single chain glycoprotein precursor (24). Any abnormality in transcription, translation, or post-translational processing and packaging could result in a limited number of phenotypic receptor abnormalities as detected by receptor-binding studies. In the present study, the 135,000 - and 95,000-mol wt subunits were identified in all subjects and were qualitatively normal. Further, 
Table V. Insulin Receptor Half-Life in a Variety of Cell Types

\begin{tabular}{|c|c|c|c|c|c|}
\hline \multirow[b]{2}{*}{ Cell type } & \multirow[b]{2}{*}{$\begin{array}{l}\text { Refer- } \\
\text { ence }\end{array}$} & \multirow[b]{2}{*}{ Methods } & \multirow[b]{2}{*}{$\begin{array}{l}\text { Manipulation } \\
\text { (if any) }\end{array}$} & \multicolumn{2}{|c|}{ Receptor half-life $(h)$} \\
\hline & & & & $\begin{array}{l}135,000 \text {-mol wt } \\
\text { subunit }\end{array}$ & $\begin{array}{l}\text { 95,000-mol wt } \\
\text { subunit }\end{array}$ \\
\hline \multirow[t]{2}{*}{ IM-9 lymphocytes } & (12) & Biosynthetically labeled/ & - & 10.8 & 10.3 \\
\hline & & anti-receptor $\mathbf{A b}$ & + Insulin & 3.8 & 2.9 \\
\hline \multirow[t]{4}{*}{ IM-9 lymphocytes } & (12) & Surface iodinated/anti- & - & 11.5 & 9.0 \\
\hline & & receptor $\mathrm{Ab}$ & + Insulin & 3.5 & 2.6 \\
\hline & (18) & $\begin{array}{l}\text { Surface iodinated/anti- } \\
\text { receptor } A b\end{array}$ & + Hydrocortisone & 6.0 & 6.6 \\
\hline & & & & \multicolumn{2}{|l|}{ Binding unit } \\
\hline \multirow[t]{2}{*}{ Chicken liver cells } & (12) & Heavy chain amino acids/ & - & \multicolumn{2}{|l|}{10} \\
\hline & & insulin binding & + Insulin & \multicolumn{2}{|l|}{10} \\
\hline \multirow{2}{*}{$\begin{array}{l}\text { 3T3-L1 } \\
\text { adipocytes }\end{array}$} & (14) & Insulin binding/tunicamycin & - & \multirow{2}{*}{\multicolumn{2}{|c|}{$8-10$}} \\
\hline & & & & & \\
\hline \multirow{2}{*}{$\begin{array}{l}\text { 3T3-L1 } \\
\text { adipocytes }\end{array}$} & (15) & Heavy chain amino acids/ & - & \multirow{2}{*}{\multicolumn{2}{|c|}{6.7}} \\
\hline & & insulin binding & & & \\
\hline \multirow{3}{*}{$\begin{array}{l}\text { 3T3-L1 } \\
\text { adipocytes }\end{array}$} & (16) & Heavy chain amino acids/ & Unregulated & \multirow{2}{*}{\multicolumn{2}{|c|}{$\begin{array}{r}14.8 \\
6.9\end{array}$}} \\
\hline & & insulin binding & + Insulin (acute) & & \\
\hline & & & + Insulin (chronic) & \multicolumn{2}{|l|}{$8.1 / 8.6$} \\
\hline \multirow{3}{*}{$\begin{array}{l}\text { 3T3-C2 } \\
\text { fibroblasts }\end{array}$} & (17) & Heavy chain amino acids/ & Unregulated & \multicolumn{2}{|l|}{10.2} \\
\hline & & insulin binding & + Insulin & \multicolumn{2}{|l|}{4.2} \\
\hline & & & + Dexamethasone & \multicolumn{2}{|l|}{18.0} \\
\hline
\end{tabular}

in the low receptor subgroup, the amount of immunoprecipitable labeled receptor was reduced in proportion to the reduction in insulin-binding capacity. Specific defects in insulin receptor biosynthesis have now been identified in three cell lines derived from the very low binding patients (patients 12, 13, and 14) with extreme insulin resistance. Preliminary studies indicate that these biosynthetic defects are of two types: a quantitative defect in precursor production and production of an abnormal precursor (29).

Examples of post-translational "synthesis" defects have been identified for the low density lipoprotein (LDL) receptor in cultured fibroblasts. In that system, the normal mature LDL receptor is a $160,000-\mathrm{mol}$ wt glycoprotein formed by post-translational modification of a 120,000 -mol wt precursor. In family studies (30) of one patient with familial hypercholesterolemia due to a deficiency in the LDL binding sites, two abnormalities were uncovered. One was the failure to process the $120,000-\mathrm{mol} \mathrm{wt}$ precursor to the mature form and the other was an abnormally long 170,000 -mol wt precursor processed to an abnormal 210,000 -mol wt product. In these cases, LDL binding was low but receptor content as measured by anti-receptor antibody binding was normal. The majority of patients with familial hypercholesterolemia, as in our patients, have reduced receptor concentration as measured by ligand and antibody binding.

We have studied the degradation rates of insulin receptors from cultured cells of normal subjects and patients with genetic syndromes of extreme insulin resistance. We have found that these patients as a group have accelerated receptor degradation. By contrast, receptor degradation rates from cells studied in vitro from patients with a secondary cause of in vivo insulin resistance due to autoantibodies to the receptor are normal. The cause of this accelerated degradation is not known, but could relate to subtle receptor abnormalities that were not detected by binding or structural studies $(1-3,5,6)$.

\section{Acknowledgments}

We wish to thank Ms. Carol Culwell for her secretarial assistance in preparation of this manuscript, and Dr. C. R. Kahn for helpful discussions in the preparations of the manuscript.

Dr. S. I. Taylor gratefully acknowledges partial research support from the American Diabetes Association (Roger Staubach Research Feasibility Grant Award). 


\section{References}

1. Grunberger, G., S. I. Taylor, R. F. Dons, and P. Gorden. 1983. Insulin receptors in normal and disease states. In Clinics in Endocrinology and Metabolism. R. N. Claylan, editor. W. B. Saunders, London. 12th ed. 191-220.

2. Roth, J., C. R. Kahn, M. A. Lesniak, P. Gorden, P. De Meyts, K. Megyesi, D. M. Neville, Jr., J. R. Gavin III, A. H. Soll, P. Freychet, I. D. Goldfine, R. S. Bar, and J. A. Archer. 1975. Receptors for insulin, NSILA-s and growth hormone: applications to disease states in man. Recent Prog. Horm. Res. 31:95-140.

3. Kahn, C. R. 1980. Role of insulin receptors in insulin-resistant states. Metab. Clin. Exp. 29:455-465.

4. Kahn, C. R., J. S. Flier, R. S. Bar, J. A. Archer, P. Gorden, M. M. Martin, and J. Roth. 1976. The syndromes of insulin resistance and acanthosis nigricans: insulin-receptor disorders in man. N. Engl. J. Med. 294:739-745.

5. Taylor, S. I., L. H. Underhill, J. A. Hedo, J. Roth, M. SerranoRios, and R. M. Blizzard. 1983. Decreased insulin binding to cultured cells from a patient with the Rabson-Mendenhall syndrome: dichotomy between studies with cultured lymphocytes and cultured fibroblasts. $J$. Clin. Endocrinol. Metab. 56:856-961.

6. Taylor, S. I., B. Samuels, J. Roth, M. Kasuga, J. A. Hedo, P. Gorden, D. E. Brasel, T. Pokora, and R. R. Engel. 1982. Decreased insulin binding in cultured lymphocytes from two patients with extreme insulin resistance. J. Clin. Endocrinol. Metab. 54:919-929.

7. Kahn, C. R., and J. M. Podskalny. 1980. Demonstration of a primary (?genetic) defect in insulin receptors in fibroblasts from a patient with the syndrome of insulin resistance and acanthosis nigricans type A. J. Clin. Endocrinol. Metab. 50:1139-1141.

8. Podskalny, J. M., and C. R. Kahn. 1982. Cell culture studies on patients with extreme insulin resistance. I. Receptor defects on cultured fibroblasts. J. Clin. Endocrinol. Metab. 54:261-267.

9. Crettaz, M., and B. Jeanrenaud. 1980. Post-receptor alterations in the states of insulin resistance. Metab. Clin. Exp. 29:467-473.

10. Schilling, E. E., M. M. Rechler, C. Grunfeld, and A. M. Rosenberg. 1979. Primary defect of insulin receptors in skin fibroblasts cultured from an infant with leprechaunism and insulin resistance. Proc. Natl. Acad. Sci. USA. 76:5877-5881.

11. Muggeo, M., C. R. Kahn, R. S. Bar, M. M. Rechler, J. S. Flier, and J. Roth. 1979. The underlying insulin receptor in patients with antireceptor autoantibodies: demonstration of normal binding and immunological properties. J. Clin. Endocrinol. Metab. 49:110-119.

12. Kasuga, M., C. R. Kahn, J. A. Hedo, E. Van Obberghen, and K. M. Yamada. 1981. Insulin-induced receptor loss in cultured human lymphocytes is due to accelerated receptor degradation. Proc. Natl. Acad. Sci. USA. 78:6917-6921.

13. Krupp, M., and M. D. Lane. 1981. On the mechanism of ligand-induced down regulation of insulin receptor level in the liver cell. J. Biol. Chem. 256:1689-1694.

14. Rosen, O. M., G. H. Chia, C. Fung, and C. S. Rubin. 1979. Tunicamycin-mediated depletion of insulin receptors in 3T3-L1 adipocytes. J. Cell Physiol. 99:37-42.

15. Reed, B. C., and M. D. Lane. 1980. Insulin receptor synthesis and turnover in differentiating 3T3-L1 preadipocytes. Proc. Natl. Acad. Sci. USA. 74:4876-4880.

16. Ronnett, G. V., V. P. Knutson, and M. D. Lane. 1982. Insulininduced down-regulation of insulin receptors in 3T3-L1 adipocytes. Altered rate of receptor inactivation. J. Biol. Chem. 257:4285-4291.
17. Knutson, V. P., G. V. Ronnett, and M. D. Lane. 1982. Control of insulin receptor level in 3T3 cells: effect of insulin-induced downregulation and dexamethasone-induced up-regulation on rate of receptor inactivation. Proc. Natl. Acad. Sci. USA. 79:2822-2826.

18. Fantus, I. G., G. A. Saviolakis, J. A. Hedo, and P. Gorden. 1982. Mechanism of glucocorticoid-induced increase in insulin receptors of cultured human lymphocytes. J. Biol. Chem. 257:8277-8283.

19. Taylor, S. I., and S. Leventhal. 1983. Defect in cooperativity in insulin receptors from a patient with a congenital form of extreme insulin resistance. J. Clin. Invest. 71:1676-1685.

20. Taylor, S. I. 1983. Receptor defects in genetic forms of extreme insulin resistance. In Regulation of Target Cell Responsiveness. K. W. McKerns, editor. Plenum Press, New York. In press.

21. Pope, J. H. 1979. Transformation by the virus in vitro. In The Epstein-Barr Virus. M. A. Epstein and B. G. Achong, editors. SpringerVerlag, Berlin. 205-223.

22. Hurley, J. N., S. M. Fu, H. G. Funkel, G. McKenna, and M. D. Scharff. 1978. Lymphoblastoid cell lines from patients with chronic lymphocytic leukemia: identification of tumour origin by idiotypic analysis. Proc. Natl. Acad. Sci. USA. 75:5706-5710.

23. Taylor, S. I., R. F. Dons, E. Hernandez, J. Roth, and P. Gorden. 1982. Insulin resistance associated with androgen excess in women with autoantibodies to the insulin receptor. Ann. Intern. Med. 97:851-855.

24. Hedo, J. A., C. R. Kahn, M. Hayashi, K. M. Yamada, and M. Kasuga. 1983. Biosynthesis and glycosylation of the insulin receptor: evidence for a single polypeptide precursor of the two major subunits. J. Biol. Chem. 258:10020-10026.

25. Ey, P. L., S. J. Prowse, and C. R. Jenkins. 1978. Isolation of pure $\mathrm{IgG}_{1}, \mathrm{IgG}_{2 \mathrm{a}}$, and $\mathrm{IgG}_{2 \mathrm{~b}}$ immunoglobulins from mouse serum using Protein A-Sepharose. Immunochemistry. 15:429-436.

26. Hedo, J. A., M. Kasuga, E. Van Obberghen, J. Roth, and C. R. Kahn. 1981. Direct demonstration of glycosylation of insulin receptor subunits by biosynthetic and external labeling: evidence for heterogeneity. Proc. Natl. Acad. Sci. USA. 78:4791-4795.

27. Yip, C. R., W. T. Yeung, and M. L. Moule. 1978. Photoaffinity labeling of insulin receptor of rat adipocyte plasma membrane. J. Biol. Chem. 253:1743-1745.

28. Taylor, S. I., J. A. Hedo, L. H. Underhill, M. Kasuga, M. J. Elders, and J. Roth. 1982. Extreme insulin resistance in association with abnormally high binding affinity of insulin receptors from a patient with leprechaunism: evidence for a defect intrinsic to the receptor. J. Clin. Endocrinol. Metab. 55:1108-1113.

29. Hedo, J. A., and S. I. Taylor. 1984. Defects in receptor biosynthesis in patients with genetic forms of extreme insulin resistance. Clin. Res. 32:560A. (Abstr.)

30. Tolleshaug, H., J. L. Goldstein, W. J. Schneider, and M. S. Brown. 1982. Post-translational processing of the LDL receptor and its genetic disruption in familial hypercholesterolemia. Cell. 30:715724.

31. Wachslicht-Rodbard, H., M. Muggeo, C. R. Kahn, G. A. Saviolakis, L. C. Harrison, and J. S. Flier. 1981. Heterogeneity of the insulin-receptor interaction in lipoatrophic diabetes. J. Clin. Endocrinol. Metab. 52:416-425.

32. Perez-Corral, F., S. de la Vina, M. Carbo, R. Barrio, R. Yturriaga, B. Perez-Meceda, M. Alonso, and M. Serrano-Rios. 1980. Rabson syndrome: model of insulin resistance due to decreased number and affinity of insulin receptors in erythrocytes. Diabetologia. 19:306. (Abstr.) 